\title{
Chapter 4 \\ Resettlement Waves, Historical Memory and Identity Construction: The Case of Thracian Refugees in Bulgaria
}

\author{
Nikolai Vukov
}

Alongside the dismantling of the communist system of public commemorations, the period after 1989 in Bulgaria was marked by an upsurge in commemorative initiatives dedicated to the history of Bulgarian people who had resettled from Eastern and Western Thrace ${ }^{1}$ a century earlier. Soon after the restoration of the Union of Thracian Associations in 1990 and the revived functioning of around 200 of its branches, commemorative and monument-building activities began to mark the history of the Bulgarian population that came from these areas. The former tradition of celebrating special days in Thracian history was taken up anew and gained enormous popularity, particularly in relation to anniversaries of the 1903 Ilinden Uprising, the commemoration of major figures of the 'Thracian movement' 2 and

\footnotetext{
${ }^{1}$ The terms for different parts of Thrace vary in the national historiographies and the public discourse of the three nation states in this area. Geographically, Thrace stretches between the central and eastern part of the Balkan mountain range to the north; the Mesta (Nestos) River to the west; the Black Sea to the east; and the Marmara and Aegean Seas to the south. The division between northern and southern Thrace generally identifies the upper part of the Thracian plain along the flow of the Marica (Evros, Meriç) River before Edirne, and the lower part - the area that stretches from this point below to the Aegean and Marmara Seas. Politically, the northern part falls within Bulgarian state territory, whilst the southern part is divided between Greece and Turkey along the water border of Marica River. The present-day Turkish part of Thrace is known as Eastern (Edirne or Turkish) Thrace, and the part within the territory of northern Greece-Western (Aegean or Greek) Thrace.

${ }^{2}$ The latter is understood in Bulgarian historiography as an organized movement since the late nineteenth century for the liberation of Thrace lands from Ottoman and Greek rule and for integrating the entire Thracian area into the Bulgarian state following the Berlin Congress of 1878. After the end of World War I, the Thracian movement was associated mainly with the fate of the refugees from Thrace and with territorial and property issues surrounding their expulsion, financial compensations and attempts to return. The movement has been increasingly linked with the activities of the so-called Thracian associations (local institutions of Thracian refugees in most Bulgarian
}

\footnotetext{
N. Vukov $(\bowtie)$

Ethnographic Museum, Bulgarian Academy of Sciences, Sofia, Bulgaria e-mail: nikolai.vukov@gmail.com

(C) The Author(s) 2015. This book is published with open access at SpringerLink.com

H. Vermeulen et al. (eds.), Migration in the Southern Balkans, IMISCOE Research Series,

DOI 10.1007/978-3-319-13719-3_4
} 
celebration of the Day of Thrace (26 March - the day Bulgarians captured Edirne Fortress in 1913). That last has been celebrated as a national holiday since 2006. Focusing mostly on the tragic events during the Second Balkan War, when Bulgarians from Eastern and Western Thrace were massacred or expelled by Ottoman troops, these commemorative events also relate to many other occasions of resettlement coerced by Ottoman and Greek authorities before the Balkan Wars and in the interwar period. These sober ceremonies and monument-building initiatives were paralleled by many other initiatives, including organized tours of Thracian descendants to the lands of their forebears, reconstruction of Bulgarian traces in Eastern and Western Thrace and trips by school and folklore groups to Turkey and Greece on national and religious holidays. All these reflect efforts of Thracian descendants to demonstrate the inexhaustible memory of the traumatic events at the beginning of the twentieth century, to affirm their identity as a 'community' through the idea of a shared trauma and its overcoming, and to reassert the symbolic connection of individuals and groups to the lost lands of their ancestors.

This chapter ${ }^{3}$ traces the gradual formation of this community of refugees and their descendants - as has resulted from several major instances of border reshaping, the resettlement of huge masses of people and traumatic events conveyed through generations which still resonate in the memory of the 'Thracian Bulgarians'. ${ }^{4}$ The chapter outlines major aspects of the collective identity of this community. These are related, for example, to a sense of common fate during and after expulsion, the community's distinctiveness from both the local population and other refugee groups in Bulgaria, and their shared awareness of unresolved issues around their status as refugees. Unlike the customary perspective of viewing Thracian refugees in Bulgarian historiography (mostly regarding them as a coherent group with explicit ethno-national characteristics), ${ }^{5}$ the emergence of this collective

towns) and with the cause of preserving the memory of the traumatic experience of the Bulgarian population from Eastern and Western Thrace.

${ }^{3}$ The research on the topic started within the framework of the project 'Resettlers and Migrants on the Two Sides of the Bulgarian-Turkish Border: Heritage, Identity, Cultural Interactions,' funded by the Bulgarian National Science Fund (2009-2012). See www.2sidesborder.org.

${ }^{4}$ The term 'Thracian Bulgarians' is commonly used in Bulgarian public discourse to identify Bulgarians who were refugees from parts of Thrace that remained outside Bulgarian state territory. Whereas only Bulgarians who were expelled from their places of birth in 1913 gained the status of 'refugees', the term was established as a general one that encompassed Bulgarians originating from Eastern or Western Thrace who moved to Bulgaria as a result of persecution, forceful expulsion, negotiations about population exchange or family choice of resettling. Although, in the Bulgarian language, the modifier 'Thracian' is used in a variety of contexts to include northern Thrace as well (e.g., Thracian music, Thracian culture, etc.), the term 'Thracian Bulgarians' is used exclusively for the Bulgarian population from Eastern and Western Thrace who resettled into Bulgarian state territory.

${ }^{5}$ The Bulgarian literature on Thracian Bulgarians and demographic processes in Thrace is extensive. For a historiographic overview of Bulgarian literature until the 1970s on the ethno-demographic aspects of the Thracian issue, see Trifonov (1976). For the most recent publications with overviews of existing literature, see Filčev (2007), Rajčevski (1994), Trifonov (1992). For a critical stance toward the interpretation of such population groups within 'national' frameworks, see the work of Theodora Dragostinova $(2006,2011)$ on the challenges of national inclusion of 
identity will be understood, rather, as a continuous process that was triggered by historical events and territorial replacements; that was moderated by international agreements, state institutions, and refugee organizations; and that was catalysed by memories of the forceful expulsion and its aftermath. With the background of an abundant literature on shifting borders, forced population movements and changing loyalties to different nation states in eastern-central and south-eastern Europe during the twentieth century (Ballinger 2003; Naimark 2001; Skran 1995; Ther and Siljak 2001), the chapter addresses the specific case of the Thracian refugees in Bulgaria - a community shaped by traumatic experiences of expulsion and by a continuous split between the new destination of residence and the nurtured hope of returning some day.

With the purpose of better clarifying the multifaceted experiences encountered by Bulgarian refugees from the Thracian area, the chapter outlines the major factors that have contributed to the emergence of the 'Thracian community' in Bulgaria. Special attention is given to the waves of refugees that fled to Bulgaria after the onset of the Balkan Wars, the forceful expulsion of Thracian Bulgarians by Ottoman troops in 1913 and the exodus of the Bulgarian population from Western Thrace after World War I. The negotiations with neighbouring states about the refugee issues and the several agreements that sought to solve the refugees' problems are regarded as yet another factor in the consolidation of this community. A separate section is dedicated to the difficulties of accommodating Thracian refugees in Bulgaria, the attempts of these refugees at adaptation to their host environment, and their constant looking back to their ancestral lands, which remained across the border. In this situation, the preservation of a collective identity encompassing Thracian refugees of different waves and different parts of Thrace seemed crucial. The Thracian associations that were developed at the end of the nineteenth century played a significant role here. Finally, the chapter sheds light on the upsurge of identity expression of Thracian Bulgarians after communist rule. Based on the author's observations of commemorative occasions and cultural events held by this community in various parts of the country, this section emphasizes the importance of historical memory for the collective identity of Thracian refugees in Bulgaria and the transfer of this symbolic resource to the generations of Thracian descendants.

\subsection{Population Movements and the Bulgarian Population in Thrace Since the Late Nineteenth Century}

With the gradual dissolution of the Ottoman Empire in the second half of the nineteenth century, Thrace became the stake of numerous conflicts between the states that emerged across this territory. The area had already been partitioned at the

Bulgarian refugees in the interwar period. On nationhood and nationalism, and how it influenced the interpretation of national minorities in Eastern Europe and the Balkans, see Brubaker (1996), Cowan (2008), Karakasidou (1997), Kitromilides (1989), Sugar (1995). 
Berlin Congress in 1878, when the northern part fell within the semi-autonomous district of Eastern Rumelia (which was united with the Principality of Bulgaria in 1885), whereas the southern part (nowadays divided between Turkey and Greece) remained under Ottoman rule. The provisions of the Berlin Congress marked the beginning of the organized movement of Bulgarians in this region for the liberation of Thrace from Ottoman domination and its incorporation within the Bulgarian state, whilst similar initiatives were pursued by the Greek population for integration of this territory into Greece. Mass migration movements and resettlements of population started at the beginning of the twentieth century, when the area became a focus of political debates and diplomatic negotiations, resulting in geographical redrawing and frontier reshaping. Without intending to provide a comprehensive historical overview here, it is important to note that the Treaty of London of May 1913 put an end to the first Balkan War and conferred to the allies all of Thrace, most of which went to Bulgaria; with the Treaty of Constantinople after the Second Balkan War the Ottoman Empire regained all of Eastern Thrace, while Bulgaria kept Western Thrace; and with the Neuilly Treaty after World War I, Western Thrace was proclaimed a mandate territory of the Entente and was occupied by French forces. This last episode was followed by the conference in San Remo in April 1920 (which ceded Western Thrace to Greece), the Sèvres Treaty of that same year (by which Greece gained a large portion of Eastern Thrace as well) and the Lausanne Treaty of 1923 (which transferred this portion back to Turkey). Later, after the crushing of Yugoslavia and Greece by Nazi Germany in April 1941, most of Western Thrace was occupied by Germany's ally Bulgaria with the purpose of 'regaining lost territories'. This continued until the autumn of 1944, when the Bulgarian troops withdrew from Western Thrace and, with the armistice signed by Bulgaria on 28 October 1944, the boundaries that were once settled at Lausanne were reaffirmed.

All of these shifts in the partitioning of Thrace and in state rule of the area resulted in altered configurations of minority and majority groups and created a pulsation of migration flows in various directions: of Muslims and Christians to states with prevailing Muslim or Christian religious identities; of Bulgarians, Greeks, and Turks to their respective nation states; and of Armenians, Jews, and Roma in circumstances of exasperated nationalistic hatred. In most cases, population movements were carried out forcibly, under conditions of territorial occupation (whether Greek, Turkish, or Bulgarian), and were accompanied by enormous human losses. Cases of ethnic cleansing or related policies of cultural homogenization were associated with almost all of the border shifts that took place. The narrative of uniting 'national' groups in separate nation states was reflected both in state policies and in administrations to assimilate or expel different minority groups, and on behalf of minority groups themselves which (after persecutions and threats of assimilation) moved back and forth to join their 'mother nations'. In parallel with the groups leaving, waves of refugees were coming into these states, seeking to find their place within new administrative, economic, and cultural systems. 
Affecting all the different ethnic and religious groups in the area, ${ }^{6}$ the population movements and refugee waves were particularly important for the Bulgarian population, which - despite the varying data and ambiguous statistics - held a substantial (and, in many respects, even prevailing) presence in the late nineteenth and early twentieth century. ${ }^{7}$ Carl Sax's ethnographic map of European Turkey in 1877 (see Appendix) provides a comprehensive illustration of the variety and interconnectedness of the different ethnic, linguistic, and religious groups of the peninsula. In the wake of the Balkan Wars in Eastern and Western Thrace, the overall population (without those who lived in Istanbul) was around one million people, with approximately equal shares of Bulgarian, Greek, and Turkish representation. The number of Bulgarians — 298,720, according to data provided by Miletič (1918)— consisted predominantly of Orthodox Christians, but included Muslims as well. ${ }^{8}$ Substantial changes in the ethnic, linguistic, and cultural representation in the area had already started after the Russian-Ottoman War of 1877-1878, when - with the march of Russian troops - thousands of Muslims were murdered or forcibly expelled from what would soon become Bulgarian state territory. ${ }^{9}$ Although some of these Muslims proceeded onward to Asia Minor, many settled in Thrace, which

\footnotetext{
${ }^{6}$ The data in Bulgarian, Greek, and Turkish sources about the ethnic and confessional characteristics of the population in Thrace vary and are often contradictory, largely due to the different principles of estimating the religious and national communities on which the sources relied. Here, I do not discuss this issue in detail, outlining instead the problem from the perspective of the Bulgarian historiogragraphy. For a detailed overview of the Bulgarian sources, see Trifonov (1992, pp. 15-18).

${ }^{7}$ Aside from the numerous accounts by scholars, diplomats, and travellers in the Balkans (E. Čelebi, A. Boué, A. Dozon, L. Niderle, etc.), a strong claim in this respect was made by various villayet censuses, decrees, and political documents of the late nineteenth century, e.g., the Ottoman decree of 1870 and the Istanbul Ambassadors' Conference of December 1876. In 1878, the French newspaper Courier d'Orient, issued in Istanbul, reported the following composition of the population in Thrace area: Muslims-190,568; Bulgarians-372,476; Greeks-147,984. The data specified also the presence of 13,710 Jews, 10,440 Armenians, and 2880 'other' ethnic groups in the area (see Šiškov 1922, p. 107). These data, as most sources about the composition of population in the area at the time, are also marked by limitations, e.g., the lack of clear identification of the applied criteria and the grounding of such classification on exclusively 'ethnic' basis. Illustrative points in this regard are the cases of the so-called Patriarchists (who are classified as either Greek or Bulgarian) and the Pomaks (who are also viewed as coming from Greek, Bulgarian, or Ottoman and Turkish origins).

${ }^{8}$ The Christians belonged either to the Bulgarian Exarchate or to the Constantinople Patriarchate, which until the first decade of the twentieth century included around 25,000 Bulgarians from the Edirne area. Apart from that, there were also 1700 Bulgarian Uniates in the area (Miletič 1918, pp. 291-300; Stojanova 2012, pp. 15-16).

${ }^{9}$ The issue of the Muslim civilian casualties and refugees as a result of this war is heavily disputed. According to the detailed account by Crampton (1990), their number was around 130,000. Around 75,000 and 80,000 of the Muslims returned after the end of the war, and only in the mid-1880s started leaving after offers from the Ottoman government of free land in Thrace or Asia Minor (Crampton 2007, p. 426). On Muslim refugees and official policies towards the Muslim minorities in Bulgaria, see also Karpat (1990) and Neuburger (2004).
} 
after the Berlin Congress was divided between Eastern Rumelia and the Ottoman Empire. This resettlement was paralleled by the mass migration of Bulgarian populations from Asia Minor and the easternmost territories of the Balkan peninsula to the north - mainly to Eastern Rumelia and the Principality of Bulgaria. ${ }^{10}$ Most of these migrants settled in areas near the border, waiting for a possibility to return to their native lands. In parallel, organized activities against Ottoman rule in the area also increased, reaching their peak with the notorious Ilinden Uprising, which broke out in Macedonia and Thrace in the summer of 1903. Ottoman forces violently suppressed the uprising, leaving dozens of villages devastated and 2500 people killed in Thrace (Filčev 1999, p. 37). This was followed by a mass wave of more than 30,000 refugees from the areas of Macedonia and Thrace to Bulgaria. Half of these refugees came from Eastern Thrace (Dimitrov 1985, p. 14).

After a wave of population movements and resettlements in the area (including the flight of Greeks from Bulgaria, Thrace, and Eastern Rumelia to Greek territories), the Balkan Wars and their aftermath brought new waves of Bulgarian refugees from Thrace. The victories of the Bulgarian army in the First Balkan War and the inclusion of a large part of Eastern and Western Thrace in Bulgaria after the London Treaty of May 1913 were chilled, however, by Bulgaria's involvement in a second war for a redistribution of the territories between the previous allies. The country's catastrophic defeat in this war led to mass migration of Bulgarian populations from Thrace, Macedonia, Dobrudža, and the western borderlands with Serbia - and the consequent withering of the Bulgarian component in these areas. Among the most notorious cases were the massacres and forced expulsion of Bulgarians by the Ottoman army in the summer of 1913, when it reoccupied the entirety of Eastern Thrace, also crossing westwards and into the pre-war frontier with Bulgaria. Dozens of Bulgarian villages were burned and hundreds of people killed or captured and sent to Anatolia. ${ }^{11}$ According to the Carnegie Report (Carnegie 1914, pp. 123-135), $50,000-60,000$ Thracian Bulgarians were murdered, which was around $20 \%$ of the Bulgarian population in Thrace at that time. Most of the villages with a Bulgarian population were destroyed and the survivors expelled from their places of origin. Fleeing to Bulgarian state territory, thousands of people (mainly women, children, and the elderly) found their death in massacres, such as those along the Marica River, in the Armaganska Valley and in the villages of Yatadžik and Avren. A detailed account of the devastation of Bulgarian communities in Thrace was systematically recorded in Miletič (1918), The Destruction of Thracian Bulgarians in 1913. The stories of survivors of these tragic events fill historical and memoir publications,

\footnotetext{
${ }^{10}$ In 1879, the overall number of refugees from Eastern Thrace alone was around 30,000, with 23,000 coming from the region of Çorlu. According to the census of 1880, just in Eastern Rumelia, 17,970 refugees settled from Eastern and Western Thrace; around the same number of refugees arrived in the Principality of Bulgaria, settling mostly in the Varna region (Dimitrov 1985, p. 13; Genadiev 1998; Šiškov 1922, p. 79).

${ }^{11}$ Concerning the destroyed villages in Eastern Thrace, the refugees and their descendants, see Brajanov (1965), Razbojnikov (1930), and Šivačev (2008). For detailed lists of the ruined Bulgarian villages in Dimotiki, Alexandroupolis, Komotini regions, see Porjazov (2009), Razbojnikov (1940), and Šalapatov (2009).
} 
forming a corpus of narrative references that recur in commemorative ceremonies of Thracian Bulgarians to this day. The refugee wave also continued in the months after the signing of the Constantinople Peace Treaty in September 1913, numbering some 15,000 people only in October of that year (see Trifonov 1985). ${ }^{12}$

The incorporation of Western Thrace into Bulgaria after the end of the Second Balkan War permitted the Bulgarian refugees from this area to return to their native places, albeit only for a short period. With the end of the Great War, in which Bulgaria was among the defeated nations, Western Thrace was occupied by Allied troops, which was followed in 1920 by the ceding of all Thrace to Greece and by another wave of refugees to Bulgaria. Later, the war between Greece and Turkey in 1918-1922 and the defeat of Greece in Asia Minor posed a new challenge for the Bulgarians living in Western Thrace, as they stirred attempts by Greek authorities to make them leave and to have refugees from Asia Minor settled in their place. This was largely facilitated by the Convention for Voluntary and Reciprocal Emigration of Minorities, signed by Bulgaria and Greece in November 1919 and implemented by a mixed commission from 1926 to 1931. Permitting the voluntary and reciprocal emigration of racial, religious, and linguistic minorities in Bulgaria and Greece, and aiming to regulate property questions for people choosing to resettle, the Convention was regarded by the Bulgarian public as enabling the destruction of the Bulgarian presence in Western Thrace (Ajanov 1942; Razbojnikov 1940; Razbojnikov and Razbojnikov 1999). Although peaceful, it effectively led to the large-scale resettlement of both Bulgarians and Greeks ${ }^{13}$ and created a new set of refugee issues related to accommodating people in their new locations and ensuring compensation for their immoveable properties. Well aware of the problems that a substantial Bulgarian population would cause for the integration of Western Thrace into the Kingdom of Greece, Greek authorities pressured entire villages to leave for Bulgaria (as Bulgarian authorities also did to many Greeks at that time). On many occasions, they hardly allowed the liquidation of their property, thus dooming them to economic disaster. ${ }^{14}$ Therefore, alongside the unresolved issue of the refugees after the Balkan Wars and World War I, the Bulgarian governments in the interwar

\footnotetext{
${ }_{12}$ Parallel with that, according to Turkish sources, 6822 Turkish families left former Ottoman territories that were incorporated within Bulgaria, and they settled in Eastern Thrace (Stojanova 2012 , p. 16). In the spring of 1914, around 10,000-12,000 Bulgarians from the Çatalca area near Istanbul were also forced to resettle (Stoyanova 2012: 16, Trifonov 1985: 185-203).

${ }^{13}$ A systematic account of the application of the Convention is provided by Theodora Dragostinova (2009, p. 186). It encompassed 1011 localities: 251 in Bulgaria, 501 in Greek (mainly Aegean) Macedonia, and 259 in Greek (Western) Thrace; a total of 101,800 Bulgarians and 52,891 Greeks submitted declarations for emigration and property liquidation; close to 40,000 on both sides emigrated but did not avail themselves of the mixed commission. Finally, some 140,000 Bulgarians and 12,000 Greeks remained in their places of birth as minorities. For the application of the Convention in the interwar period, see Dimitrov (1982), Dragostinova (2008), Ladas (1932), and Penkov (1946).

14 The overall number of Bulgarian refugees from Western Thrace and Aegean Macedonia in 1924-1925 was 48,680 (Dragostinova 2006, p. 553).
} 
period had to find solutions for support, accommodation, and future compensation of this refugee wave as well. ${ }^{15}$

For the refugees from Eastern Thrace, who were prevented from returning to their places of origin, the major issue was still the compensation for the properties that they had left behind. The question was posed many times in the first half of the twentieth century, but it was systematically suspended and has remained practically unresolved to this day. During World War I, the Ottoman authorities clearly stated that it was not necessary for Bulgarians to return to their lands and that the empire would accept the possibility of compensating them for their properties. At the end of the war, however, the issue was delayed due to the onset of the GrecoTurkish War of 1919-1922. The withdrawal of the Greek occupation forces from Eastern Thrace at the end of the war was seen by Thracian refugees as the last hope of returning to their native places. However, Turkish authorities refused to allow the return of Bulgarian refugees and, actually, even those families that had already taken the risk of coming back were pressed to leave. Bulgarian schools and churches were destroyed or closed, and on former Bulgarian and Greek properties, the Turkish state settled its own refugees (Turks, Albanians, and people from Bosnia). Finally, after long negotiations, in 1925 the Ankara Agreement was signed, which was supposed to regulate the payment of compensation to Bulgarians from Eastern Thrace and Asia Minor for the properties that they had left behind in the expulsions between 1912 and 1925 (see Ladas 1932; Kumanov 1971; Peeva 2006; Popnikolov 1928). This agreement excluded the possibility of resettlement, but accepted the refugees' rights to the properties left behind. In 1927, many documents were collected in Bulgaria for enforcement of the procedure. However, in contrast to the Mollov-Kafandaris Agreement between Bulgaria and Greece in 1927, when compensations were organized within a short period, for the refugees in Eastern Thrace this issue remained an open one. Whilst in the 1940s the economic situation in Turkey was difficult enough to undertake such a step, after World War II the two states belonged to different ideological blocs and the communist government in Bulgaria considered it unacceptable to 'ask' for financial compensation from a capitalist state. It was only after the end of communist rule that the issue of compensating refugees from Eastern Thrace was posed anew, triggering various political initiatives and contributing to the enhancement of memorial practices by Thracian descendants.

\footnotetext{
${ }^{15}$ Later on, after the crushing of Yugoslavia and Greece by Nazi Germany in April 1941, most of Western Thrace was under the occupation of Bulgaria and there was a possibility for Thracian refugees to resettle back to their native places in Greece. This situation continued, however, until the autumn of 1944, when after the withdrawal of the Bulgarian troops from Western Thrace, this population moved back to Bulgaria again.
} 


\subsection{Accommodation, Adaptation, and Identity Construction of Thracian Refugees}

The waves of refugees from Thracian territories over the course of several decades posed significant challenges to the Bulgarian state for their settlement, economic support, and social adjustment. ${ }^{16}$ In the first years after 1878 , as well as after the Ilinden Uprising (1903), the difficulties comprised mainly the weak economic and administrative capacity of the state to provide adequate support, as well as the continued hope that the resettlement was temporary, at least until a new redistribution of Ottoman territories in South-Eastern Europe. The forcible expulsion of the Bulgarian population from Thrace in 1913 was particularly dramatic — not only because of the scale of the refugee wave but also since it occurred in the context of mass migration from other territories (Macedonia, Dobrudža, Greece, and the western borderlands) to Bulgaria. ${ }^{17}$ The number of refugees after the wars amounted to more than $5 \%$ of the population in Bulgaria at the time, ${ }^{18}$ and this created enormous difficulties in providing them with land, housing, and a basic means of subsistence. In the years between the Great War and the mid-1930s, the Bulgarian state introduced several laws and regulations for the accommodation of refugees, ${ }^{19}$ founded several institutions with regional departments, secured separate financial means, and took a large external loan - all aimed at a solution to the refugee problem. The first step in the integration of Thracian refugees in Bulgaria concerned their reception and distribution for settlement in the country. They were distributed predominantly in the east, in the regions of Burgas, Yambol, Sliven, Varna, and Šumen, but in fact all parts of the country hosted groups of refugees from this area. ${ }^{20}$ The flow of refugees continued in the following years, complemented by refugees from Western Thrace.

\footnotetext{
${ }^{16}$ For details of the social and economic difficulties with the accommodation of refugees after World War I in Bulgaria, see Dimitrov (1985) and Genov (1935).

${ }^{17}$ The mass groups of migrants and refugees in that period were complemented by Russians who came to Bulgaria after the October Revolution and by the Armenian population from the Ottoman Empire.

${ }^{18}$ For a detailed systematization and insightful interpretation of the refugee issues in interwar Bulgaria, see Dragostinova (2006). The officially recognized refugees (i.e., people who arrived in Bulgaria between October 1912 and December 1926) included 55,940 families with a total of 253,067 members. There were also many people who resettled but did not acquire legal refugee status. The overall estimate of refugees is about 280,000, which was $5 \%$ of the Bulgarian inhabitants in 1926 . Around $48 \%$ of these people came from Greece (Aegean Macedonia and Western Thrace), $25 \%$ from the Ottoman Empire (Eastern Thrace), $12.5 \%$ were born in what became Yugoslavia (Vardar Macedonia and the West Ends in Serbia), $11 \%$ were from Romania (Southern Dobrudža), and 3\% arrived from Asia Minor (ibid., p. 553).

${ }^{19}$ Among those are the Law of Housing Crisis (1919), the Law for Settling of Refugees and Securing their Means of Living (1920), the Law of Agricultural Settling of Refugees (1925), the Law of Agricultural Settling of Refugees through the Loan Received from the League of Nations (1926), and the Regulation-Law for Easing the Refugee Situation (1937).

${ }^{20}$ In the Burgas region around 48,332 people stayed; Sofia-35,446, Petrič-34,900; Haskovo-22,346; Plovdiv-19,729; Momčilgrad-14,103; Varna-11,908; Stara Zagora-9311, Šumen - 6218; and in the regions of Vidin, Vratsa, Veliko Tărnovo, Kjustendil, and Smoljan-
} 
According to information from the Bulgarian Directorate of Refugees, until 1931, in the Burgas region alone (the most immediate destination for refugees from Eastern Thrace), 12,155 families were settled—9837 from Eastern and 2318 from Western Thrace. They were distributed across 73 villages, and their numbers totalled more than 60,000 , two thirds of which were from Eastern Thrace. ${ }^{21}$

The conditions in which these refugees lived were extremely poor, and a substantial part of this population died of hunger, poverty, and disease. Having left behind fertile land, cattle, and housing, they were entirely dependent on the support of the state and the local population. The most pressing need was to accept the arriving refugees and to shelter them, at least temporarily (see Hitilov 1932; Gergova 2012; Uzunova 2005). Until the early 1920s, most of them were living in stables, sheep pens, and half-destroyed houses, and exposed to malaria and tuberculosis. In the aftermath of the Great War, the state was virtually incapable of supporting refugees materially and financially. Thus, the aid that it provided was largely symbolic and was distributed for only 3 years after the war. In 1920, the government of Aleksandăr Stambolijski managed to supply refugees with land, wood, financial loans, and free medical care; however, organization of this support was chaotic, and it did not reach all of those in need (Dragostinova 2006, p. 558; Šivačev 1987). It was only at the end of the 1920 s that 42,510 refugee families received loans with the support of the League of Nations, which enabled them to build small houses, named šaronki (after René Charron, main coordinator of the settlement procedure). The construction of these houses marked in fact one of the first systematic attempts to provide refugees with proper housing, thus also settling them permanently. ${ }^{22}$ Evidence of these constructions can be seen today in many towns and villages in Bulgaria, where they form the core of still-existing refugee neighbourhoods. The survival of the newcomers was also closely connected with the issue of agricultural land: most of these territories were infertile and poor-in very humid or dry areas, mostly in south-eastern Bulgaria. Yet, even when the allocation of Thracian refugees involved previously unused or unproductive lands, the local population often reacted against the refugees' settlement and resisted their integration.

The difficult economic and social conditions were accompanied by serious emotional trauma among the refugees, resulting from painful memories of expulsion from their places of origin, recollections about people and families that had died or were lost, nostalgia about their homes and villages, and difficulty in adapting as refugees in the new setting. There were numerous situations when refugees from a village or even family were separated and were additionally traumatized by not being able to find each other. Despite the compassion and support shown at first by local populations, the feeling that they were alien and unwanted in their new destinations

between 1000 and 5000 people. For detailed accounts of refugees' settlement in Bulgaria, see Brajanov $(1965,1970)$.

${ }^{21}$ For Thracian refugees' accommodation in the Burgas region, see Ajanov (1939) and Kosatev (1975).

22 The payment of this loan was bound, however, with a high interest rate and contributed to the bankruptcy of most refugees and to new economic disasters. 
contributed further to their frustration. Many people attempted to return to their native places, but only for a short period-long enough to realize the impossibility of settling again in an environment that had changed completely, as a foreign land, with no familial or recognizable traces. The political developments after World War I made it virtually impossible to go back and with the Ankara Agreement of 1925 this impossibility was formalized. Memories among the generation that experienced these events of violent expulsion persisted in subsequent years and became an acute source of painful associations and mental reverie. The possibilities for visits became even rarer after World War II, when the chances to go for tourism to 'capitalist' Turkey were exceptional. The Association of Thracian Bulgarians managed to organize several group visits to Turkey, but the routes were firmly fixed, and possibilities for seeing their places of origin were limited.

What one may observe as a recurring theme in the public representations of Thracian Bulgarians during the years after their resettlement was their insistence on the 'unique' character of their fate and their separate identity among other communities in Bulgaria. The grounds for such an assertion of separate identity were several, but they often oscillated around the idea of the shared cultural characteristics of Bulgarians in Thrace, a common historical fate, and the specific contours of their collective memory. All these were posed mostly in comparison to the Macedonian refugees or to the local groups where Thracian Bulgarians were settled. In narratives gathered until today at various fieldwork occasions, Thracian descendants point out as inherently unique to their community their 'exceptional industriousness and diligence' combined with 'love of agricultural work', 'docile character', and 'naïve approach to life'. A comment that regularly comes up in conversation is the contrast with refugees from Macedonia, who are stereotypically labelled as 'people of the mountains', 'hot-blooded', 'eagerly involved in politics' and sharing a 'more dynamic and fervent worldview'. Thracian Bulgarians' descriptions of the local population vary depending on the areas where they are settled, but a customary point is that Thracian refugees outdo them in almost all aspects of work activity - in land cultivation, industriousness, innovation and trade. In memoirs and narrative self-descriptions of Thracian refugees, these cultural characteristics are regularly accompanied by examples of the tragic fate of Thracian Bulgarians as a persecuted and expelled population. Concrete cases are mentioned illustrating this fate - telling either of crimes committed against family members or of the poverty and starvation after their arrival in Bulgaria. The extreme suffering of Bulgarians from Thrace is stressed as resulting mainly from the nation state's lack of adequate attention to their cause. A common theme is the minimal (if any) reparations for the prosperous lands and real estate that they owned in the past.

With regard to the years immediately after their arrival in Bulgaria, it is important to note that most refugees were split between the choice (when such existed) of going back to their native places — gaining the status of a minority there — or the possibility of remaining permanently in their new destinations, as citizens of the Bulgarian state. Staying in Bulgaria, however, put them in a situation of being 'refugees' among the other co-nationals, thus both uniting with the 'national homeland' and also keeping a distance, as having their native land outside the state borders. 
This split has determined a major aspect of their identity until today. It finds expression in their self-awareness as being 'the only real Bulgarians' and also in their constant gaze over the border - that is, where their ancestors were born and lived. Nurtured by recent memories of their native places and their resettlement to new locations, this dividing line in the group identity of Thracian Bulgarians dominated the overall experience of the first refugee generation and that of their children. In the course of time, and with a diminishing hope that refugees might be able to go back to their place of origin, permanent resettlement in Bulgaria was gradually accepted. Emphasis on the cultural specificity of Thracian Bulgarians then came to the foreground. Nevertheless, the motif of the split in their territory of belonging, and the contribution of this split to their traumatic experience, can still be traced among descendants of Thracian Bulgarians today.

\subsection{The Role of Thracian Associations}

The maintenance of the collective identity of Thracian Bulgarians was influenced by various factors that were projected at national, public, and private levels. Whilst there was a visible attempt on behalf of the state to embrace the refugees' cause as a symbol of national martyrdom and to use it as an argument in negotiations with state neighbours (see Detrez, this volume), an important role for the survival and adaptation of refugees has been played by various charity initiatives organized by the Bulgarian public after major refugee waves. A crucial role in the maintenance of the collective identity of this refugee community was played by the numerous Thracian associations which were established in late nineteenth century with the purpose of facilitating the social integration and cultural adaptation of refugees in Bulgaria. ${ }^{23}$ After the creation of the first Thracian association 'Strandža' in Varna (1896) and the Inauguration Congress of the Thracian Union in Burgas (1897), the movement founded numerous branches across the country, which — despite merging with Macedonian associations in different periods of their existence-maintained a well delineated position on the specificity of the Thracian cause.

With the end of the Balkan Wars and the new massive waves of refugees to Bulgaria, the Thracian movement substantially changed the orientation of its activities. Whilst the original purpose was the joining of all Thrace to Bulgaria and the protection of the Thracian population's interests by the Great Powers, later, its activities were focused primarily on the refugees' land settlement, accommodation, and social and cultural adjustment. With the remainder of Western Thrace within Bulgarian state territory after 1913, the main focus was on Eastern Thrace, as well as on the refugees that came from this region. In May 1914, the 'Odrinska Trakija' (Edirne Thrace Association) was established in Sofia, with the goal of fighting for the return of the expelled Bulgarians from Eastern Thrace, but in the meantime, to facilitate their temporary settlement. The association issued a newspaper, distributed

\footnotetext{
${ }^{23}$ For the history of the Thracian movement and the Thracian associations, see Filčev (1999).
} 
memoirs and other historical publications, and organized public lectures. It proclaimed 13 March, the day of capturing the Edirne Fortress, as the main day of the association. In December 1918, near Edirne a congress was held which issued a resolution addressed to the Bulgarian government asking it to pay more attention to Thracian issues, as they tended to be overshadowed by those of the Macedonian refugees. In a separate resolution, a request was made to representatives of the Great Powers from the Entente and the USA to recognize the right of Thracian Bulgarians to return to the lands of their ancestors and to regain their occupied properties under the supervision of the Allied forces and the Bulgarian government.

After the congress, the organization quickly expanded, and association branches were created in many towns (e.g., Ajtos, Stara Zagora, and Provadija). ${ }^{24}$ In 1921, the first issue was published of Trakija newspaper, which became a main organ of the Thracian movement. A year later, the Thracian youth association was established in Varna, soon followed by similar units in Plovdiv, Burgas, Haskovo, and other towns in southern Bulgaria. Open to people under 30 years of age, these units organized events such as speeches and seminars, evening readings, celebrations of special dates, theatre performances, and sports events. In 1925 the first Thracian students' association and in 1930 the first Thracian women's association were established in Varna. Both had numerous followers and developed branches in other parts of the country. The forms and names of these associations were different - some were called 'patriotic groups' whilst others identified themselves as 'emigrant associations', 'charity and cultural unions', and the like - but the scope of their activities was largely the same. Parallel to the wide range of educational and cultural activities that were carried out, they tirelessly issued declarations to Bulgarian and international institutions condemning the destruction of Bulgarian ethnic and cultural traces in Thrace, and also organized public demonstrations concerning the most pressing problems of the refugee population.

A peak of these activities was the protest against the 'Agreement of Friendship between Bulgaria and Turkey' that was signed in Ankara in 1925. According to the agreement, the real estate of Bulgarians who had resettled after 18 October 1912 until the signing of the treaty, as well as the real estate of Muslims who resettled during the same period from Bulgaria to the Ottoman Empire and Turkey, would become the property of the state within which these estates had remained. The Thracian organization vehemently protested against the agreement, as - according to its claims - it 'transferred' the ownership rights of Thracian Bulgarians to the Turkish state and, thus, virtually precluded the refugees' possibility to return and claim inheritance of ancestral lands. By putting all Bulgarians from Thrace into the category of 'migrants', the Ankara Agreement was accused of neglecting the evidence of persecution and violent expulsion in many of these resettlements - particularly in the events of 1913, for which Thracian Bulgarians were internationally recognized as 'refugees'. The Ankara Agreement's claim that most of these people had resettled 'voluntarily'

\footnotetext{
${ }^{24}$ By 1924 there were already 44 associations, 93 in 1925 and 151 in 1926. In 1927, the number of the Thracian associations was 170, 200 in 1928 and 235 in 1932, with around 20,000 active members (See Filčev 2007: 81-99).
} 
as 'migrants' was interpreted as enabling Turkish authorities to view refugees' previous properties as belonging to the Turkish state. Despite the rigorous protests of Thracian activists against the Ankara Agreement, in 1926 the Bulgarian Parliament ratified it, in the hope that the agreement might permit Thracian refugees to receive compensation. However, at the request of the Turkish government, the negotiations were paused in the following year and the agreement did not come into force.

A similar situation of Thracian associations' protests surrounded the MollovKafandaris Agreement between Greece and Bulgaria in December 1927. Though this agreement seemingly settled the financial issues, it was considered by Thracian associations as ensuring the legal framework for what was termed a 'de-Bulgarization policy' in Western Thrace. A major criticism raised along this line was that, on many occasions when Bulgarians were pressed to resettle, the compensation for their property was merely symbolic; yet the church, monastery, and school properties which belonged to church municipalities were liquidated. The very act of signing both these agreements was considered to be a heavy blow to the cause of Thracian refugees, who saw them as a betrayal of their interests and as downgrading the trauma they had experienced. Disappointment with these political developments led to a visible decrease in the organization's public activity. Following the military coup of 19 May 1934, which forbade all political parties and social organizations in the country, the Supreme Executive Committee of the organization was dissolved. What continued to function were 'Trakija' cultural and educational associations, as well as the youth, women's, and students' branches, but their activities also diminished. In the late 1930s, the commemorative meetings at Petrova Niva (to mark anniversaries of the Ilinden Uprising and to celebrate the Day of Thrace) were postponed, to be revived only after World War II.

Establishment of the government of the Fatherland Front in September 1944 nourished the hope that the Thracian question would finally reach resolution. In October 1944, the Supreme Executive Committee of the Thracian organization was restored and soon after that, a decision was taken to revive all former Thracian associations. This was partly related to the Thracian organization's gradual adjustment to the political order in Bulgaria during communist rule, as expressed in the co-opting of its leaders to the Communist Party and its reinterpretation of the struggles for national liberation and unification along the lines of the official communist ideology. In the three decades that followed, the network of Thracian associations expanded its activity, mainly in terms of educational and cultural events. In 1950, the Thracian organization was transformed into the Union of Thracian Associations in Bulgaria (STDB) and celebrations of the Ilinden Uprising and of the tragic events in the village of Yatadžik (Madžarovo) began to be held on an annual basis. Following the widespread fashion of building public monuments in communist Bulgaria, a monument to Kapitan Petko Vojvoda was unveiled in Haskovo in 1955 and another one in Varna in 1959. A grand monument to the Ilinden Uprising was unveiled in Petrova Niva in 1958, with some 5000 people present at the ceremony. In a period of restrictions on political claims other than those of the Communist Party, Thracian associations gradually indulged themselves with celebrations of historical dates and figures, organization of meetings and cultural activities, and propaganda work 
about the building of communism in the country. However, despite these regular activities and adherence to the postulates of the ruling ideology, in 1977, a decision of the Communist Party closed down the Union of Thracian Associations (alongside the Union of Macedonian ones) - the official explanation being that it had exhausted its main purposes. The central committee and network of the associations were dissolved again and the local units joined with the Fatherland Front clubs, which had an overt ideological profile as representing the antifascist resistance. Remaining unclear in terms of actual reasons, the dissolution of the refugee organizations largely blocked the organized meetings and activities of Thracian refugees for about a decade and they could revive their activities with new force only at the start of the 1990 s.

\subsection{Reasserting Thracian Identity After 1989}

With the end of communist rule in Bulgaria, the Union of Thracian Associations and its previous constituent associations were revived and the Trakija newspaper resumed publication. Starting from those towns with a substantial presence of Thracian refugees' descendants (e.g., Haskovo, Kardžali, Burgas, Yambol, Stara Zagora, and Varna), the remembrance practices for the traumatic historical events soon covered again the entire country. Sites that became major focuses of commemorative initiatives were the meetings in Madžarovo, Ilieva Niva, and Avren (dedicated to the victims of the 1913 persecutions), the annual celebrations in Petrova Niva (dedicated to the Ilinden Uprising) and meetings dedicated to prominent fighters for the Thracian cause, such as Kapitan Petko Vojvoda and Dimităr Madžarov. All these occasions included the building of monuments and commemorative structures, which expanded the memorial topography of Thracian refugees' history. Organization of these events involved a common ritual script-with reports on historical data, moving speeches, and solemn honouring of the dead. Focusing on Thracian refugees' suffering and fights, they outlined the significance of the latter in national history and highlighted the patriotic nature of their commemoration. Other important elements at these gatherings were the presentation of refugee folklore traditions on stage by various singing and dancing groups. In fact, many of these occasions were linked to other cultural events in towns and villages, facilitating a merging of the commemorative gatherings with festive presentations of regional folklore.

Alongside the commemorative occasions in Bulgaria, many initiatives were organized in the Thracian territories of Greece and Turkey, with the purpose of reviving traces of the former Bulgarian presence there and to assert affiliation with ancestral lands. This was made possible by the ability after 1989 to travel abroad freely, and many cross-border activities were organized to fill the vacuum that had existed during the decades of impeded access to former homelands. ${ }^{25}$ Over the last

\footnotetext{
${ }^{25}$ Such memorial visits are organized nowadays also by descendants of Greeks who left their native places in Bulgaria between 1906 and the 1920s, as well as by Turks who left for Turkey in
} 
two decades, numerous excursions were made to ancestral places of origin in Turkey and Greece, most of them organized by the Thracian associations. These visits involved people of different ages and generations, and followed a ritual scheme that included meetings with local authorities, the presentation of gifts, visits to surviving churches and cemeteries, planting of trees and flowers from Bulgaria, and paying respect to victims ${ }^{26} \mathrm{~A}$ frequent location for these visits across the border is Edirne, where a policy for reviving the Bulgarian historical and cultural traces has resulted in the restoration of sites, such as the nineteenth century churches of saints George, Constantine, and Elena and the Bulgarian cemetery, among others. Carried out with the collaboration of Bulgarian state institutions and local authorities, the revival of such sites brought a visible increase in visits of Thracian descendants to Eastern Thrace, and their regular involvement in various cultural events in this area. The tours of refugees' descendants and folklore groups to towns and villages in Greece and Turkey hold a firm place in the cultural calendar of the Union of Thracian Associations and are inseparable from the list of commemorative events year-round.

All these cultural events and initiatives outline the present-day contours of a group identity that has developed over a century and has several main constituents. These include the painful memories of the suffering experienced, the awareness of the 'national' significance of the Thracian cause, the notion of cultural heritage preservation, and the claim for rightful compensation despite decades without a positive resolution. These constituents have been regular points of reflection in all the commemorative gatherings of the Thracian organization and in the various oral narratives and published memoirs produced by members of this community. They are reflected in the goals that the Union of Thracian Associations declared in its Statute of 1990: defending and accomplishing the Bulgarian national cause in Thrace, obtaining the right of return and resurrection of the Bulgarian culture in Eastern and Western Thrace, development of Thracian spirit, and preservation of Thracian heritage (Ustav 1990). ${ }^{27}$ The Statute of 1990 omits some of the clichés derived from the communist ideology before 1989, but it retained others that have been used repeatedly by Thracian Bulgarians since the beginning of their organized movement. As such, it testifies to several claims that have remained relatively unchanged for more than a century and that continue to shape the collective memory and identity of Thracian descendants.

Although nowadays few promoters of the Thracian cause nurture illusions that it may be possible to go back to reside in the places of their ancestors, the idea of protecting the traces of the former Bulgarian habitation - alongside receiving financial compensation for what was lost-is still alive (Kozarova 2007). Clear indicators of this are the revived negotiations with Turkey after 1989 for resolving the issue

different resettlement waves throughout the twentieth century, mostly during the peak of the assimilation campaign launched by the communist state in the 1980s (on the latter, see Vukov 2012).

${ }^{26}$ For a detailed presentation of these ritual activities, see Ganeva-Rajčeva (2011).

${ }^{27}$ The first statute of the Thracian associations was accepted at the inaugural Congress of 1907 and since then it has gone through several modifications depending on political circumstances of the interwar period and after 1944, but its core ideas have generally remained the same until today. 
of Thracian Bulgarians' property in Eastern Thrace. In 1991, at the initiative of the Union of Thracian Associations in Bulgaria, an agreement was reached between Bulgaria and Turkey to discuss the problematic issues between the two countries. Since 1992, several attempts to discuss the application of the Ankara Agreement have been made by the Bulgarian Parliament, by government ministers, and during exchange visits of ambassadors and politicians to Bulgaria and Turkey. Despite the demonstrated willingness to carry out such negotiations, a general suspicion has appeared that, once again, the attempts at solving this may be postponed until the deadline of 100 years when the agreement's application ultimately expires. A peak in the Bulgarian state's efforts to reach a solution to this issue was the proposal of Bulgarian EU representatives and the ensuing decision of the European Parliament to bind Turkey's membership application to the EU with the requirement of resolution of the existing property disputes with Bulgaria. Following this decision, ${ }^{28}$ Bulgaria and Turkey started new negotiations in 2009 and a mass campaign was initiated in Bulgaria to provide documentation on property in the lands left behind, including real estate that had belonged to the Bulgarian Exarchate and Bulgarian cultural monuments in contemporary Turkey. A special department was created within the State Archives of Sofia where documents and diverse testimonies that could verify the property rights of Thracian Bulgarians were collected, validated, translated from Ottoman Turkish, and analysed. These recent developments stirred new impulses in the community of Thracian descendants to collect necessary testimonies and mobilize family and kinship networks to assert ownership of properties lost a century ago. Thus, once again, as in previous decades, memories of the expulsion of the Bulgarian population from Thracian lands were revived by a suddenly emerging hope for successful resolution to this protracted issue, consolidated by the idea that the decades of dedication to the Thracian cause has not been in vain.

Doubtless, such claims have strongly influenced identity processes amongst Thracian refugees as a 'community', one whose members were dispersed across the country and could maintain their contacts mostly through such ritual gatherings. The reaffirmation of belonging to a community of origin and participation in the social network during commemorations and cultural events were also unavoidably linked with demonstrating a position on the issue of due compensation and with an expectation of at least a symbolic gain from what had been lost by their ancestors. However, despite the unconcealed attention to the claimed possession of once-owned property, the contours of Thracian memory and identity did not remain confined to the idea of material compensations: sometimes, it even contradicted or overtly opposed this idea. One of the directions of this line of thought was prompted by alternative voices coming from members of the Thracian community about the need to overcome the accumulated traumas and to stay open to the possibilities of cross-border cooperation, thus virtually annulling the relevance of any property claims. Yet another direction has been promoted by the view of Thracian belonging as a largely 'symbolic realm', which cannot be subdued by political and territorial negotiations, but rather persists as a timeless identity mark across generations. The oscillation between these

\footnotetext{
${ }^{28}$ www.europe.bg/en/htmls/page.php?archive $=2008-04 \&$ archive_day $=22 \&$ category $=374$
} 
several poles of interpretation is what marks the identity expression of Thracian descendants today - in narrative forms, commemorative activities, and public events honouring the history of Thracian Bulgarians.

\subsection{Conclusion}

Developing over the course of a century and in the context of traumatic historical circumstances, the various aspects of Thracian identity can hardly be covered by such a brief outline as provided in this chapter. Several points are worth reemphasizing, however, in the form of concluding remarks. The first is related to the problem of Thracian Bulgarians as a 'community'. It was formed gradually by population groups coming from different towns and villages of Eastern and Western Thrace and in the midst of different cases of expulsion, resettlement, and accommodation in new places. Despite their different experiences and individual examples, the refugees and migrants from Thrace embraced a reference to their area of origin as something able to unite them and to express as a 'shared' fate. Nowadays, the term 'a Thracian person' (trakiets) is immediately recognized and connected with particular historical experiences by every Bulgarian, not only those of refugee descent. Although initially the term was supposed to encompass primarily the survivors of the most dramatic refugee waves (e.g., the massacres of 1913 and the expulsions from Western Thrace in the early 1920s), over time it stretched to encompass almost any of the other cases related to Thracian resettlement to Bulgaria. Even more importantly, it has also come to involve all subsequent generations and every one of the descendants of Thracian Bulgarians. In fact, personal identification as 'second', 'third', and later generations of Thracian refugees is widespread among members of this community in their narratives about place of origin and their relatives' fates in the past.

This specificity of Thracian Bulgarians as a 'community' is even more striking when considered against the background of the various directions of resettlement of Thracian Bulgarians in the country. Their presence was visible in large and small towns, where they were gradually involved in social and cultural activities, but up until today they have remained distinguishable by the neighbourhoods where their grandparents settled and by the specific family stories that they possess and reproduce on various occasions. Although Thracian Bulgarians were never considered a 'minority' within the national body, they have always remained distinguished from both the rest of the 'local' Bulgarian population and other refugee communities, such as those from Macedonia. This distinction is strongly evident in community meetings on various occasions and at commemorative events, where Thracian Bulgarians assert their specific historical memories. In situations of these kinds, Thracian Bulgarians from different parts of the country conduct a tour to honour the numerous people lost in the traumatic events, to acknowledge the 'everlasting presence' of historical trauma, and to reaffirm their belonging to the Thracian 'community' and their support of the 'Thracian cause'. In opposition to the growing distance from the 
events of the past, Thracian Bulgarians have persistently maintained their stories of persecution and expulsion, their genealogical memory, and the recurring commemorative occasions as ways to preserve a sense of collective identity.

Finally, it is important to emphasize the role of state borders in shaping the idea of community among Thracian Bulgarians. The border is a recurring reference point in the memories and narratives of Thracian Bulgarians until the present day. In the dramatic days of the persecution and flight of refugees to Bulgaria in 1913, the state border was perceived as a 'horizon', the reaching of which would bring salvation from impending death. The border was a line whose crossing brought radical change in refugees' lives, as well as a line to approach in later attempts to return to the lands of ancestors. In the dynamic context of territorial redistribution after the collapse of the Ottoman Empire, borders were not only created to delineate the territories of nation states, but they were also changed, shifted, assaulted, and reclaimed, exploding in a range of military actions and population moves. These metamorphoses of borders in Thrace not only determined the fates of Thracian Bulgarians as rooted out and directed to the territory of the Bulgarian state, but also influenced subsequent hopes and expectations - particularly the intention of returning or despair at no longer being able to go back. Heavily loaded with historical associations and traumatic memories handed down through generations, the border and its meaning in terms of separation from the territories of ancestors has played another constitutive role for the identity of the Thracian community. While it functioned (and still does) as a firmly established topoi in the various testimonies and memoir accounts of Thracian Bulgarians, it is also evoked in recollections during commemorative ceremonies, and it shapes the behaviour of those descendants who have traversed the border areas on various tours and commemorative occasions over the past two decades. These symbolic meanings of the border-alongside the continuing claim for recognition of the experienced suffering and the effort to maintain a collective identity over time - will certainly guide the practices of this community in the future.

Open Access This chapter is distributed under the terms of the Creative Commons Attribution Noncommercial License, which permits any noncommercial use, distribution, and reproduction in any medium, provided the original author(s) and source are credited.

\section{References}

Ajanov, G. (1939). Malko Tărnovo i negovata pokrajnina [Malko Tărnovo and its vicinity]. Burgas: Kulturno blagotvoriteino družestvo 'Trakija'.

Ajanov, G. (1942). Narodnosten lik na Zapadna Trakija [A national outlook of Western Thrace]. Burgas: Kulturno blagotvoriteino družestvo 'Trakija'.

Ballinger, P. (2003). History in exile: Memory and identity at the borders of the Balkans. Princeton: Princeton University Press.

Brajanov, T. (1965). Bălgarski bežanci ot Trakija, rodni sela i kăde sa zaseleni v Bălgarija: Čast părva [Bulgarian refugees from Thrace, native villages and sites of resettlement in Bulgaria: Part one]. Izvestija na Trakijskija naučen institut, 1, 117-146. 
Brajanov, T. (1970). Bălgarski bežanci ot Trakija, rodni sela i kăde sa zaseleni v Bălgarija: Čast vtora [Bulgarian refugees from Thrace, native villages and sites of resettlement in Bulgaria: Part two]. Izvestija na Trakijskija naučen institut, 2, 207-237.

Brubaker, R. (1996). Nationalism reframed: Nationhood and the national question in the new Europe. New York: Cambridge University Press.

Carnegie (1914). Report of the international commission to inquire into the causes and conduct of the Balkan Wars. Washington, DC: Carnegie Endowment for International Peace.

Cowan, J. K. (2008). Fixing national subjects in the 1920s Southern Balkans: Also an international practice. American Ethnologist, 35(2), 338-356.

Crampton, R. (1990). The Turks in Bulgaria, 1878-1944. In K. Karpat (Ed.), The Turks of Bulgaria: The history, culture and political fate of a minority (pp. 43-78). Istanbul: Isis Press.

Crampton, R. (2007). Bulgaria. New York: Oxford University Press.

Dimitrov, G. (1982). Malcinstveno-bežanskijat văpros v bălgaro-grăckite otnošenija 1919-1939 [The minority and refugee issue in Bulgarian-Greek relationship, 1919-1939]. Blagoevgrad: (no publisher).

Dimitrov, G. (1985). Nastanjavane i ozemljavane na bălgarskite bežanci [Accommodation and land supply of the Bulgarian refugees]. Blagoevgrad: (no publisher).

Dragostinova, T. (2006). Competing priorities, ambiguous loyalties: Challenges of socioeconomic adaptation and national inclusion of the interwar Bulgarian refugees, Nationalities Papers, 34(5), 549-574.

Dragostinova, T. (2008). Speaking national: Nationalizing the Greeks of Bulgaria, 1900-1939, Slavic Review, 67(1), 154-181.

Dragostinova, T. (2009). Navigating nationality in the emigration of minorities between Bulgaria and Greece, 1919-1941, East European Politics and Societies, 23, 185-212.

Dragostinova, T. (2011). Between two motherlands: Nationality and emigration among the Greeks of Bulgaria. Ithaca: Cornell University Press.

Filčev, I. (1999). Trakijskata organizacija v Bălgarija (Istoriko-hronologičen zapis) [Thracian organization in Bulgaria (historical and chronological record)]. Sofia: (no publisher).

Filčev, I. (2007). Trakijskijat văpros i trakijskoto dviženie v Bălgarija [The Thracian question and the Thracian movement in Bulgaria]. Sofia: Akademično izdatelstvo 'Prof. Marin Drinov'.

Ganeva-Rajčeva, V. (2011). Migration, memory, heritage: The example of Thracian Bulgarians, descendants of refugees and resettlers from Eastern Thrace. Bălgarski folklor, 3(Special Edn.), 48-66.

Genadiev, G. (1998). Bežancite văv Varnensko, 1879-1908 [Refugees in the Varna region, 18791908]. Varna: VMRO.

Genov, G. (1935). Njojskijat dogovor i Bălgarija [The Neuilly Treaty and Bulgaria]. Sofia: Hr. G. Danov.

Gergova, L. (2012). Migracii, migrantski obštnosti i gradsko razvitie prez XX vek (po primeri ot Haskovo) [Migration, migrant communities and urban development in the twentieth century (on examples from Haskovo)]. www.2sidesborder.org/Resettlers\%20and\%20Migrants/index. html.

Hitilov, K. (1932). Selskostopanskoto nastanjavane na bežancite 1927-1932 [The agricultural accommodation of refugees, 1927-1932]. Sofia: Glavna direkcija na bežancite.

Karakasidou, A. (1997). Fields of wheat, hills of blood: Passages to nationhood in Greek Macedonia, 1870-1990. Chicago: University of Chicago Press.

Karpat, K. (Ed.). (1990). The Turks of Bulgaria: The history, culture and political fate of a minority. Istanbul: Isis Press.

Kitromilides, P. (1989). Imagined communities and the origin of the national question in the Balkans. European History Quarterly, 19, 149-194.

Kosatev, T. (1975). Nastanjavane na bežancite v Burgaski okrăg 1919-1932 [Accommodating refugees in Burgas region, 1919-1932]. Istoričeski pregled, 2, 57-69.

Kozarova, P. (2007). Iztočnotrakijskijat imuštestven problem: proučvanija, analizi, dokazatelstva (1993-2007) [The property issues related to Eastern Thrace: Explorations, analyses, proofs (1993-2007)]. Sofia: Petekston. 
Kumanov, M. (1971). Văzstanovjavane na diplomatičeskite otnošenija meždu Bălgarija i Turcija 1923-1926 [The restoration of diplomatic relationships between Bulgaria and Turkey, 1923 1926]. Istoričeski pregled, 2, 69-82.

Ladas, S. (1932). The exchanges of minorities: Bulgaria, Greece and Turkey. New York: Macmillan.

Miletič, L. (1918). Razorenieto na trakijskite bălgari prez 1913 godina [The destruction of Thracian Bulgarians in 1913]. Sofia: Daržavna pečatnitsa.

Naimark, N. (2001). Fires of hatred: Ethnic cleansing in twentieth-century Europe. Cambridge: Harvard University Press.

Neuburger, M. (2004). The orient within: Muslim minorities and the negotiation of nationhood in modern Bulgaria. Ithaca: Cornell University Press.

Peeva, K. (2006). Ankarskite spogodbi: Diplomatičeski uspeh ili otstăplenie ot bălgarskite interesi [Ankara agreements: Diplomatic success or withdrawal from Bulgarian interests]. Istoričesko bădešte, 1-2, 117-140.

Penkov, S. (1946). Bălgaro-grăcki malcinstveni problemi sled Părvata Svetovna vojna [Bulgarian-Greek Minority issues after the First World War]. Sofia: (no publisher).

Popnikolov, D. (1928). Bălgarite ot Trakija i spogodbite na Bălgarija s Gărcija i Turcija [Bulgarians from Thrace and the agreements of Bulgaria with Greece and Turkey]. Sofia: (no publisher).

Porjazov, D. (2009). Pogromăt nad trakijskite bălgari prez 1913 g.: razorenie i etničesko iztreblenie [The pogrom on Thracian Bulgarians in 1913: Devastation and ethnic destruction]. Sofia: Akademično izdatelstvo 'Prof. Marin Drinov'.

Rajčevski, S. (1994). Iztočna Trakija: istorija, etnosi, preselenija (XVI-XX vek) [Eastern Thrace: History, ethnic groups, resettlements ( sixteenth to the twentieth century)]. Sofia: Otečestvo.

Razbojnikov, A. S. (1930). Selo Bulgarkjoj [The village of Bulgarkyoj]. Trakijski sbornik, 2, $63-$ 103.

Razbojnikov, A. S. (1940). Obezbălgarjavaneto na Zapadna Trakija, 1919-1924 [The debulgariazation of Western Thrace]. Sofia: Trakijski Naučen Institut.

Razbojnikov, A. S., \& Razbojnikov, S. A. (1999). Naselenieto na Južna Trakija s ogled na narodnostnite otnošenija $v$ 1830, 1878, 1912, 1920 [The population of Southern Thrace with regards to ethnic relationships in 1830, 1878, 1912, 1920]. Sofia: Karina M.

Šalapatov, D. (2009). Bălgarskite hristijanski selishta v Zapadna Trakija [Bulgarian Christian villages in Western Thrace]. Izvestija na Trakijskija naučen institut, 9, 194-201.

Šiškov, S. (1922). Trakija predi i sled Evropejskata vojna [Thrace before and after the European War]. Plovdiv: Izdatelstvo 'Hr. G. Danov'.

Šivačev, S. (1987). Bežanskijat văpros v Plovdivski okrăg [The refugee issue in the Plovdiv region]. Izvestija na muzeite ot Južna Bălgarija, 13, 183-199.

Šivačev, H. (2008). Proučvane na selo Enikjoj, Uzunkjuprijsko, Odrinski okrăg [A study of Enikyoj village, Uzunkyupryu region, Edirne area]. Sofia: Askoni Izdat.

Skran, C. (1995). Refugees in interwar Europe: The emergence of a regime. Oxford: Clarendon Press.

Stojanova, V. (2012). Izselvanija na bălgarite ot Iztočna Trakija sled balkanskite vojni (19131945) [Resettlements of Bulgarians from Eastern Thrace after the Balkan wars (1913-1945)]. www.2sidesborder.org/Resettlers\%20and\%20Migrants/index.html.

Sugar, P. (Ed.) (1995). Eastern European nationalism in the twentieth century. Lanham: American University Press.

Ther, P., \& Siljak, A. (Eds.) (2001). Redrawing nations: Ethnic cleansing in East-Central Europe, 1944-1948. Lanham: Rowman \& Littlefield.

Trifonov, S. (1976). Bălgarski proučvanija za narodonaselenieto na Trakija [Bulgarian explorations about the population of Thrace]. Vekove, 5, 48-55.

Trifonov, S. (1985). Bežanskijat văros v bălgaro-turskite otnošenija (1913-1918) [The refugee issue in Bulgarian-Turkish relationships (1913-1918)]. Izvestija na Bălgarskoto istoričesko družestvo, 37, 169-203. 
Trifonov, S. (1992). Trakija: Administrativna uredba, političeski i stopanski život, 1912-1915 [Thrace: Administrative rule, political and economic life, 1912-1915]. Sofia: Kapitan Petko Vojvoda.

Ustav (1990). Ustav na Săjuza na Trakijskite kulturno-prosvetni družestva v NR Bălgarija $i$ na družestva 'Trakija' [Code of the Union of Thracian cultural-educational association in the people's Republic of Bulgaria and of 'Thrace' associations]. Sofia: Săjuz na Trakijskite družestva v Bălgarija.

Uzunova, K. (2005). Razselvaneto na trakijskite bežanci v Haskovskija region i merkite na mestnite i daržavnie vlasti za tjahnoto nastanjavane [The settlement of Thracian refugees in Haskovo region and the measures of local and state authorities for their accommodation]. Izvestija na Trakijskija naučen institut, 6, 190-211.

Vukov, N. (2012). Izselvanija, pamet i vazpomenatelni zavrăshtanija. Otbeljazvaneto na "Văzroditelnija" proces v Bălgarija [Resettlements, memory and commemorative return visits: The noting of the so called "revival" process in Bulgaria]. www.2sidesborder.org/ Resettlers\%20and\%20Migrants/index.html.

Nikolai Vukov works at the Ethnographic Museum of the Bulgarian Academy of Sciences, Sofia, Bulgaria. His research interests are related to monuments, museum representations and public commemorations in Eastern Europe after 1945; communist rule and post-communist transition; and state borders and migrant identities. 